Anna Zellma ${ }^{1}$

Uniwersytet Warmińsko-Mazurski w Olsztynie

Wydział Teologii

\title{
(Nie)kwestionowane granice decyzyjności pedagoga w ksztaltowaniu obrazu świętości wśród dzieci?
}

O tym, jak ważna i znacząca jest rola pedagoga w integralnym wychowaniu dzieci, nie trzeba chyba obecnie nikogo przekonywać. Jego aktywność zawodowa w przedszkolu i szkole wiąże się z realizacją różnych celów i zadań opiekuńczych, dydaktycznych, wychowawczych ${ }^{2}$. Obejmuje także często trudne i odpowiedzialne działania ukierunkowane na udzielanie dzieciom wsparcia i pomocy w kształtowaniu obrazu świata, rozpoznawaniu różnych wartości oraz kryteriów i sposobów ich wyboru czy też w nabywaniu podstawowych umiejętności społecznych oraz w formowaniu postaw moralnych i religijnych ${ }^{3}$. Z tym powiązane jest ukazywanie właściwych wzorców osobowych oraz motywowanie do ich naśladowania. W tak określonej aktywności zawodowej pedagog niejednokrotnie odwołuje się zarówno do własnej wiedzy, osobistych poglądów i przekonań, uznawanych wartości, jak też do doświadczenia i intuicji. Niemniej, istotną rolę spełnia nie tylko obowiązujące pedagoga prawo oświatowe, ale także przyjęta w placówce oświatowej koncepcja wychowania. Wraz z założeniami programowymi zajęć edukacyjnych są to ważne komponenty, które określają kierunek aktywności pedagoga w zakresie integralnego wychowania dzieci. Wpływają one też na decyzje podejmowane przez pedagoga, dotyczące kształtowania obrazu świętości wśród dzieci. Niestety, wciąż niewiele jest opracowań,

\footnotetext{
${ }^{1}$ Anna Zellma - profesor nauk teologicznych; kierownik Katedry Teologii Pastoralnej i Katechetyki na Wydziale Teologii UWM w Olsztynie; członek zarządu Stowarzyszenia Katechetyków Polskich; konsultor Komisji Wychowania Katolickiego Konferencji Episkopatu Polski; członek The European Equipe for Catechesis (EEC) i Polskiego Towarzystwa Teologicznego. Autorka trzech monografii oraz ponad 200 artykułów naukowych i popularnonaukowych z zakresu katechetyki integralnej, pedagogiki chrześcijańskiej i nauk o rodzinie.

2 Zob. np. Ustawa z dnia 7 września 1991 r. o systemie oświaty, „Dziennik Ustaw” $1991 \mathrm{nr} 95$, poz. $425 \mathrm{z}$ późn. zm.

${ }_{3}$ Zob. tamże; więcej o tym np. w: Cz. Banach, Wartości w systemie edukacji, http://www.wsp. krakow.pl/konspekt/konspekt7/banach7.html [dostęp 12.10.2016].
} 
które zwracałyby uwagę na te kwestie. Sporadycznie pisze się o roli nauczycieli religii w ukazywaniu postaci świętych jako wzorów osobowych, często jest to ujęcie konfesyjne, wprost związane z działalnością katechetyczną Kościoła katolickiego ${ }^{4}$. Marginalnie traktuje się ważną rolę wszystkich pedagogów, którzy niezależnie od tego, jakie prowadzą zajęcia edukacyjne w przedszkolu i szkole, za istotny uznają chrześcijański system wartości ${ }^{5}$. Dyskusje toczą się natomiast wokół poszukiwania nowych wzorców osobowych i autorytetów ${ }^{6}$. Coraz częściej pedagodzy próbują odwoływać się do postaci fikcyjnych i magicznych, znanych ze współczesnych bajek, filmów i gier komputerowych ${ }^{7}$. Postacie te dostarczają dzieciom wielu informacji o świecie i innych ludziach oraz pozwalają towarzyszyć bohaterom i identyfikować się z nimi, a przez to w znacznym stopniu wpływają na tworzenie się świata dziecięcych znaczeń. Pedagodzy ci upatrują w nich szansę na dialog z wychowankami. Z jednej strony, w odniesieniu do nauczania i wychowania dzieci, jest to uzasadnione, gdyż bazuje na tym, co bliskie dzieciom, z drugiej natomiast (zwłaszcza gdy w zachowaniu bajkowych postaci granica dobra i zła zostaje zatarta, a niekiedy nawet pojawiają się praktyki czysto okultystyczne i magiczne), przyczynić się może do powstania nieprawdziwego obrazu człowieka oraz pogrążania się w świat marzeń, fikcji i magii. Nie ma tu miejsca na odwołanie do trwałych, fundamentalnych, a zarazem uniwersalnych wartości, które służą integralnemu wychowaniu dzieci.

W kontekście poczynionych uwag rodzą się następujące pytania: Czy pedagog jest ograniczany w swoich decyzjach dotyczących kształtowania obrazu świętości wśród dzieci, a jeżeli tak, to czym i jaki charakter mają te ograniczenia? Jakimi możliwościami dysponuje pedagog w zakresie przekraczania istniejących ograniczeń związanych z kształtowaniem obrazu świętości wśród dzieci? Szukanie odpowiedzi na tak postawione pytania wymaga najpierw wyjaśnienia pojęć: „pedagog”, „dziecko” i „decyzyjność pedagoga” oraz krótkiego scharakteryzowania procesu kształtowania obrazu świętości wśród dzieci. Pytanie pierwsze składa się z trzech pytań szczegółowych. Należy je jednak potraktować jako oka-

${ }^{4}$ Zob. np. J. Bagrowicz, Towarzyszyć wzrastaniu. Z dyskusji o metodach i środkach edukacji religijnej młodzieży, Toruń 2006; M. Kasprzak, Miejsce św. Józefa w katechezie na I, II i III etapie edukacyjnym, „Katecheta” 58(2012) nr 12, s. 4-10; I. Werbiński, Błogosławiona Karolina Kózka jako wzór osobowy dla współczesnej młodzieży żeńskiej, „Ateneum Kapłańskie” 134(2000), s. 33-40.

${ }_{5}^{5}$ Zob. np. F.W. Wawro (red.), Pedagog wobec wyzwań współczesności, Lublin 2010.

${ }^{6}$ Zob. np. M.A. Bednarska (red.), O autorytecie w wychowaniu i nauczaniu, Wrocław 2009; M. Kołodziejski (red.), Twórcza codzienność w kształceniu $i$ wychowaniu: teoria i praktyka edukacyjna, Pułtusk 2014; D. Łużyńska (red.), Autorytet w wychowaniu i edukacji, Józefów 2013.

7 Zob. np. K. Budzyńska, Bajki terapeutyczne i ich rola, „Życie Szkoły” 11(2013), s. 8-9; C. Langier, Bajki i baśnie jako źródto wartości w wychowaniu moralnym dzieci, w: Edukacja dziecka wobec wyzwań i zagrożeń ponowoczesności, red. C. Langier, K. Śleziński, Częstochowa 2014, s. 97-208; E. Lubina (red.), Małe dziecko w przestrzeni społecznej i edukacyjnej, Warszawa 2012. 
zję do przedstawienia założeń programowych pracy pedagoga w obszarze kształtowania obrazu świętości wśród dzieci oraz zalecanych rozwiązań metodycznych. Znaczące wydaje się przy tym odwołanie do takich dokumentów oświatowych, jak np. „Ustawa o systemie oświaty”, „Karta nauczyciela”, „Podstawa programowa kształcenia ogólnego” 10 i „Program wychowawczy przedszkola lub szkoły"11. Odpowiedź na pytanie drugie sprowadza się do ukazania możliwości przekraczania barier związanych z kształtowaniem obrazu świętości wśród dzieci poprzez zaprezentowanie innowacji pedagogicznych służących temu celowi.

\section{Uwagi definicyjne}

Pojęcia kluczowe dla niniejszego opracowania są powszechnie stosowane zarówno w naukach społecznych i teologicznych, jak też w mowie potocznej. $\mathrm{Z}$ uwagi na ich szeroki, a niekiedy pozbawiony precyzji obszar semantyczny, na potrzeby niniejszego tekstu należy je doprecyzować.

Przez pojęcie ,pedagog” w niniejszym opracowaniu rozumie się osobę zatrudnioną w przedszkolu lub szkole, która posiada odpowiednie (określone w prawie oświatowym) kwalifikacje do pracy w charakterze nauczyciela prowadzącego zajęcia edukacyjne lub do pracy na stanowisku pedagoga ${ }^{12}$. Aktywność zawodowa tej osoby koncentruje się wokół realizacji zadań dydaktyczno-wychowawczych i profilaktycznych, określonych m.in. w programie wychowawczym i profilaktycznym placówki opiekuńczo-wychowawczej lub oświatowej oraz w podstawie programowej kształcenia ogólnego. Takie rozumienie pojęcia „pedagog” nie ogranicza się tylko do czynności zawodowych wykonywanych w ramach zatrud-

${ }^{8}$ Ustawa z dnia 7 września 1991 r. o systemie oświaty, poz. 425 z późn. zm.

9 Ustawa z dnia z dnia 26 stycznia 1982 r. Karta Nauczyciela, „Dziennik Ustaw” z 1982 nr 3, poz. 19, z późn. zm. tekst jednolity „Dziennik Ustaw” 2016 r. poz. 1379.

${ }^{10}$ Rozporzadzenie Ministra Edukacji Narodowej z dnia 17 czerwca 2016 r. zmieniajace rozporządzenie w sprawie podstawy programowej wychowania przedszkolnego oraz ksztatcenia ogólnego w poszczególnych typach szkót. Załacznik nr 1. Podstawa programowa wychowania przedszkolnego dla przedszkoli oraz innych form wychowania przedszkolnego, „Dziennik Ustaw” z 2016, poz. 895; Rozporzadzenie Ministra Edukacji Narodowej z dnia 17 czerwca 2016 r. zmieniajace rozporzadzenie $w$ sprawie podstawy programowej wychowania przedszkolnego oraz kształcenia ogólnego w poszczególnych typach szkót. Załacznik nr 2. Podstawa programowa kształcenia ogólnego dla szkót podstawowych, „Dziennik Ustaw” z 2016, poz. 895.

${ }^{11}$ Ustawa z dnia 7 września 1991 r. o systemie oświaty, poz. 425 z późn. zm.; Rozporządzenie Ministra Edukacji Narodowej z 18 sierpnia 2015 r. w sprawie zakresu i form prowadzenia w szkotach i placówkach systemu oświaty działalności wychowawczej, edukacyjnej, informacyjnej i profilaktycznej w celu przeciwdziałania narkomanii, „Dziennik Ustaw” z 2015, poz. 1249.

12 Zob. np. Cz. Kupisiewicz, M. Kupisiewicz, Stownik pedagogiczny, Warszawa 2009, s. 132; B. Milerski, B. Śliwerski (red.), Pedagogika. PWN Leksykon, Warszawa 2000, s. 144; W. Okoń, Nowy stownik pedagogiczny, Warszawa 1998, s. 285. 
nienia na stanowisku pedagoga w przedszkolu lub szkole. Przeciwnie, odnosi się do wszystkich nauczycieli, którzy posiadają odpowiednie kwalifikacje pedagogiczne do pracy zarówno w przedszkolu i szkole, jak też do prowadzenia zajęć pozaszkolnych.

Kolejnym kluczowym dla niniejszego opracowania pojęciem jest pojęcie „dziecko". Wskazuje ono na wychowanków w okresie wczesnego dzieciństwa (3-6 rok życia) i późnego dzieciństwa (7-10 rok życia) ${ }^{13}$. Pierwszy z wymienionych etapów rozwoju obejmuje dzieci w tzw. wieku przedszkolnym. Drugi natomiast odnosi się do dzieci w tzw. młodszym wieku szkolnym. Na tych etapach rozwoju daje się zauważyć u dzieci dynamiczne przemiany nie tylko w sferze fizycznej, ale także intelektualnej, emocjonalnej i społecznej. Dzieci są aktywnym podmiotem edukacji przedszkolnej i szkolnej, których psychika jest szczególnie podatna na wpływy wychowawców, co wydaje się znaczące dla aktywności pedagoga, związanej z kształtowaniem obrazu świętości wśród tej grupy wychowanków.

Na potrzeby niniejszych analiz przyjmuje się również, że termin „decyzyjność pedagoga" oznacza możliwość decydowania ${ }^{14}$ przez niego o podejmowanych działaniach dydaktyczno-wychowawczych. Możliwość ta wiąże się bezpośrednio ze specyficznym podejściem do zadań określonych w prawie oświatowym, programie wychowawczym i profilaktycznym oraz w programach kształcenia i w podręcznikach do nauczania określonego przedmiotu, stawianych pedagogom. Pośrednio wskazuje, że pedagog może sam podejmować decyzje w obszarze zadań, które ma realizować. Chodzi tu nie tyle o możliwość wyboru celów i treści, ile o sposób ich prezentowania i akcentowania. Nie mniej istotne jest kierowanie się w swojej pracy i życiu osobistym uniwersalnymi wartościami oraz odwoływanie do nich w procesie nauczania i wychowania dzieci. Tego rodzaju wartości spełniają ważną rolę w ukazywaniu dzieciom właściwego obrazu świętości i motywowaniu ich do naśladowania świętych osób.

\section{Ksztaltowanie obrazu świętości wśród dzieci}

Nie ulega wątpliwości, że kształtowanie obrazu świętości integralnie wiąże się z rozwojem życia religijnego ${ }^{15}$. Dotyczy bowiem wyobrażeń, jakie czło-

${ }_{13}$ Tamże, s. 82; D. Waloszek, Dziecko, w: Encyklopedia pedagogiczna XXI wieku, red. T. Pilch, t. 1, Warszawa 2003, s. 883-895.

${ }_{14}$ Decyzyjność, http://sjp.pwn.pl/sjp/; 3028672 [dostęp 10.10.2016].

15 Warto zauważyć, że w literaturze to zagadnienie nie występuje wprost. W analizach poświęconych rozwojowi religijnemu autorzy sporadycznie piszą o roli świętych, np. w kontekście kształtowania się obrazu Boga i wychowaniu do świętości. Zob. np. S. Kulpaczyński, Psychologia rozwojowo-wychowawcza nie tylko dla katechetów, Lublin 2009; Z. Marek, M. Szczęsny, B. Szołda, T. Warchał, Bóg w przedszkolu i szkole. Zarys katechezy przedszkolnej i wczesnoszkolnej, Kraków 2000; P. Mąkosa, Rola katechezy w ksztattowaniu obrazu Boga u dzieci w młodszym wieku szkolnym, w: Katecheza dzieci, red. M. Zając. Lublin 2009, s. 169-185. 
wiek ma zarówno na temat Boga, jak i świętości konkretnych osób - nie tylko ogłoszonych przez Kościół błogosławionymi lub kanonizowanymi, ale także pojedynczych ochrzczonych, pełniących różne funkcje we wspólnocie Kościoła. Na obraz świętości składają się m.in. cechy przypisywane Bogu, który ze swej natury jest święty oraz osobom wyjątkowo bliskim Bogu, powołanym do szczególnej misji w Kościele i świecie ${ }^{16}$. Obok tego znaczące są wyobrażenia dziecka na temat powołania osób ochrzczonych do naśladowania Chrystusa w jego świętości oraz dążenia do doskonałości we wszystkich sferach aktywności i na każdym etapie życia poprzez ascezę, modlitwę wspólnotową i indywidualną, ewangeliczne przeżywanie cierpienia, pracę, apostolstwo i kierownictwo ducho$w^{17}$. Wyobrażenia na temat świętości spełniają ważną rolę w rozwoju religijnym człowieka, a zwłaszcza w odkrywaniu sposobów życia Ewangelią w codziennym życiu oraz naśladowaniu Chrystusa w różnych sytuacjach, m.in. poprzez uczciwą naukę i pracę, życie w prawdzie, okazywanie szacunku innym ludziom, troskę o biednych, chorych, starszych i potrzebujących pomocy, zaangażowanie na rzecz budowania pokoju w rodzinie, szkole, społeczności lokalnej, ojczyźnie czy też udział w różnego rodzaju inicjatywach wolontariackich. Co więcej, mają one charakter dynamiczny. Kształtują się bowiem przez całe życie człowieka i pod wpływem wielu czynników. U ich podstaw znajduje się wiedza i przeżycia z okresu wczesnego dzieciństwa, które w ciągu rozwoju osobowego i religijnego ulegają pewnym zmianom ${ }^{18}$. Często jednak wyobrażenie osoby świętej, ukształtowane w dzieciństwie, jest utrwalane. Trudno je modyfikować i korygować, zwłaszcza że współcześnie środowisko rodzinne nie sprzyja wychowaniu do świętości ${ }^{19}$.

Uwzględniając stwierdzenia psychologów na temat rozwoju dziecka w wieku przedszkolnym (3-7 r.ż. $)^{20}$, można przyjąć, że dokonujące się zmiany rozwojowe w tym okresie sprzyjają również kształtowaniu się obrazu świętości. Wiążą się

${ }^{16}$ Szerzej na temat świętości zob. np. G. Baran, Świętość. II. W Biblii, w: Encyklopedia katolicka, t. 19, red. E. Gigilewicz, Lublin 2013, kol. 401-403; A. Rybicki, Świętość. III. W teologii, w: Encyklopedia katolicka, t. 19, kol. 403-404.

${ }_{17}$ Tamże; zob. także P. Królikowski, M. Rusecki, Świętość Kościoła, w: Encyklopedia katolicka, t. 19, kol. 404-407.

${ }^{18}$ Por. np. K. Furmanik, Wczesne uwarunkowania obrazu Boga, http://www.opoka.org.pl/ biblioteka/I/IP/kf_obraz-boga.html, [dostęp: 22.10.2016], s. 1-8; A. Żurek, Style wychowania doświadczane w dzieciństwie jako korelaty religijności osób dorostych. Pilotażowe badania empiryczne wśród rodziców dzieci przygotowujących się do sakramentu Eucharystii, „Studia Paradyskie” 25(2015), s. 229-246.

${ }_{19}$ S. Kulpaczyński, Psychologia rozwojowo-wychowawcza nie tylko dla katechetów, s. 80-81, 111-117, 140-144.

${ }^{20}$ Zob. np. tamże; A.I. Brzezińska, K. Appelt, B. Ziółkowska, Psychologia rozwoju człowieka, Sopot 2016; M. Cholewa, Psychologia rozwojowa, Kraków 2015; M. Przetacznik-Gierowska, G. Makiełło-Jarża, Psychologia rozwojowa i wychowawcza wieku dziecięcego, Warszawa 1992; H.R. Schaffer, Psychologia dziecka, Warszawa 2005. 
bowiem z rozwojem emocjonalnym, społecznym i religijnym dziecka. Zdobywając nowe doświadczenia, dziecko stawia pytania o poznawaną rzeczywistość, co przyczynia się nie tylko do odkrywania otaczającego świata, ale także do rozpoznawania ważnych postaci i upodabniania się do nich ${ }^{21}$. Stopniowo dziecko nawiązuje kontakt z osobami spoza rodziny, odnajduje własne miejsce w gronie rówieśników i innych osób. Procesom tym towarzyszy odkrywanie różnorodnych reguł postępowania i stosowanie ich w kontaktach międzyludzkich ${ }^{22}$. Dziecko próbuje - głównie na drodze identyfikowania się i naśladowania - upodabniać się do znaczących dla niego osób dorosłych i rówieśników oraz postaci z bajek, opowiadań i filmów. Uczy się rozpoznawać to, co dobre, i to, co złe, interpretować codzienne doświadczenia, odkrywać piękno świata oraz wartościować przez pryzmat otaczających je ludzi ${ }^{23}$. Dziecko w wieku przedszkolnym zaczyna przejmować od dorosłych system zasad oraz norm społecznych i religijnych, liczyć się z tymi normami i zgodnie z nimi postępować ${ }^{4}$. Stara się też naśladować praktyki religijne dorosłych, co sprzyja socjalizacji ${ }^{25}$, a jednocześnie zapoczątkowuje proces kształtowania się obrazu świętości u dziecka. Pomoc rodziców, krewnych, starszego rodzeństwa i nauczycieli w poprawnej interpretacji codziennych doświadczeń dziecka, zwłaszcza ukazywanie codziennych sytuacji jako okazji do poznawania Boga i naśladowania Go, modlitwy, okazywania miłości Bogu i bliźnim oraz do czynienia dobra (np. podczas zabawy, drobnych obowiązków, nauki, zajęć w przedszkolu), sprzyja kształtowaniu obrazu świętości. Pozwala bowiem udzielać dzieciom pomocy nie tylko w odkrywaniu, że świętym jest Bóg, ale także, że do świętości są powołani wszyscy - niezależnie np. od wieku, wyglądu zewnętrznego, posiadanych talentów, wykształcenia, miejsca zamieszkania. W tym kontekście ważne miejsce zajmuje ukazywanie dzieciom, kto może zostać świętym i dlaczego. Chodzi tu zwłaszcza o wspieranie wychowanków w wieku przedszkolnym w zrozumieniu prawdy, że świętość nie jest czymś wyjątkowym, lecz wiąże się z dobrym zachowaniem, przestrzeganiem zasad obowiązujących w domu i przedszkolu, czynieniem dobra, oraz okazywaniem miłości Bogu i bliźnim w codziennych, małych i drobnych zdarzeniach (np. podczas zabawy w przedszkolu i w domu, wykonywaniu drobnych czynności, o które proszą rodzice). Stąd też, za istotne w procesie kształtowania obrazu świętości wśród dzieci w wieku przedszkolnym, należy uznać powiązanie treści zarówno ze stawianymi przez dziecko pytaniami, jak też z jego codziennymi doświadczeniami. Wówczas udzielane wychowankowi odpowiedzi i prowadzone pogadanki stają

${ }^{21}$ S. Kulpaczyński, Psychologia rozwojowo-wychowawcza nie tylko dla katechetów, s. 33-124.

22 Tamże.

${ }^{23}$ Konferencja Episkopatu Polski, Podstawa programowa katechezy Kościoła katolickiego $w$ Polsce, Kraków 2010, s. 16.

${ }^{24}$ Tamże, s. 15-16.

25 Tamże. 
się okazją do poznawania podstawowych pojęć religijnych i modlitw, odkrywania, na czym polega świętość oraz motywowania do kontaktowania się z Bogiem i naśladowania Go. Mogą też pomóc w odkrywaniu, kim są święci i budowaniu ich prawdziwego obrazu oraz w kształtowaniu przyjaznego odniesienia do innych i rozwijaniu umiejętności społecznych, które są niezbędne w traktowaniu innych ludzi z miłością, dobrocią, życzliwością i troską ${ }^{26}$.

W kolejnym etapie rozwoju, określanym terminami „okres wczesnoszkolny”, „młodszy wiek szkolny”, „późne dzieciństwo” (od 7 r.ż. do 10 r.ż.) ${ }^{27}$, zwiększa się samodzielność dziecka. Jego aktywność przechodzi od zabawy do uczenia się. Dziecko podejmuje nowe role społeczne w różnych środowiskach (np. $\mathrm{W}$ rodzinie, szkole, grupie rówieśniczej) ${ }^{28}$. Na bazie dotychczasowego poziomu rozwoju umysłowego, emocjonalnego, społecznego oraz fizycznego następuje rozwój wrażeń, spostrzeżeń, mowy i pamięci logicznej. Kształtują się również pojęcia i postawy wobec świata, innych osób i siebie samego ${ }^{29}$. Dziecko stopniowo ujawnia tendencję do uczestnictwa w życiu społecznym (np. w klasie, szkole, na zajęciach pozalekcyjnych i pozaszkolnych). W coraz większym stopniu potrafi liczyć się ze zdaniem grupy i ocenami nauczyciela oraz panować nad własnymi emocjami. W wieku ok. 10 lat dziecko przechodzi od akceptacji norm moralnych, dokonującej się pod naciskiem autorytetu dorosłych i z uwagi na sankcje zewnętrzne (stadium moralności heteronomicznej), a zaczyna je przestrzegać ze względu na potrzebę pozyskania sympatii otoczenia, opinię środowiska i zabieganie o aprobatę (stadium socjonomii) ${ }^{30}$. To przechodzenie na wyższy poziom rozwoju moralnego sprzyja ukazywaniu dzieciom właściwego obrazu świętości oraz organizowaniu różnych form aktywności społecznej, które umożliwiają czynienie dobra i okazywanie miłości bliźnim. $Z$ tym wiąże się również potrzeba wzbudzania wśród wychowanków w młodszym wieku szkolnym motywacji do aktywnego udziału w różnych formach wolontariatu i dobrego, społecznie pożądanego, postępowania $\mathrm{w}$ domu, szkole, $\mathrm{w}$ grupie rówieśniczej. W ten sposób można nie tylko mówić o świętości, ale także wspierać dzieci w kształtowaniu postawy zaufania Bogu, pokładania w Nim nadziei oraz naśladowania Chrystusa

26 Tamże.

27 Ten etap rozwoju dziecka nazywany jest także późnym dzieciństwem. Zob. R. Stefańska-Klar, Późne dzieciństwo. Młodszy wiek szkolny, w: Psychologia rozwoju człowieka, t. 2, Charakterystyka rozwoju człowieka, red. B. Harwas-Napierała, J. Trempała, Warszawa 2000, s. 130-162; L. Wołoszynowa, Młodszy wiek szkolny, w: Psychologia rozwojowa dzieci i młodzieży, red. M. Żebrowska, Warszawa 1982, s. 522-663.

28 Tamże.

29 P.K. Smith, Rozwój społeczny, w: Psychologia rozwojowa, red. P.E. Bryant, A.M. Colman, tłum. A. Bezwińska-Walerjan, Poznań 1995, s. 65-66.

30 S. Kulpaczyński, Psychologia rozwojowo-wychowawcza nie tylko dla katechetów, s. $137-144$. 
i świętych poprzez uczynki miłosierdzia i świadectwo wiary w szkole, w rodzinie, w kontaktach rówieśniczych.

W procesie kształtowania obrazu świętości wśród dzieci w młodszym wieku szkolnym istotną rolę spełniają zmiany rozwojowe dotyczące sfery życia religijnego. Religijność uczniów w wieku wczesnoszkolnym ma charakter autorytarno-moralny ${ }^{31}$. Jej cechą charakterystyczną jest dominacja uzewnętrznionych form, uzależnionych od autorytetu i wzoru osób znaczących, a szczególnie rodziców i wychowawców ${ }^{32}$. Praktyki religijne (w tym także modlitwa) traktowane są w kategoriach obowiązku i posłuszeństwa ze względu na osoby starsze. Stąd też uwidacznia się w nich wyraźnie naśladownictwo. Dzieci postrzegają Boga głównie jako stróża powinności moralnych i religijnych, a nie jako źródło i cel. Ich religijność cechuje też rytualizm. Dzieci w okresie wczesnoszkolnym „mechanicznie ujmują relacje między znakami materialnymi i religijnymi a ich duchowymi skutkami" ${ }^{33}$. Stopniowo jednak angażują się w praktyki religijne. U niektórych dzieci uwidacznia się szczególna wrażliwość na modlitwę oraz wspólnotę religijną i świętych. Odpowiednie przygotowanie i przeżycie sakramentu pokuty i pojednania oraz Eucharystii sprzyja rozbudzaniu pragnienia naśladowania Chrystusa w czynieniu dobra. Wymaga jednak nie tylko przekazu odpowiednich wiadomości, ale także organizacji doświadczeń związanych z realizacją przykazania miłości Boga i bliźniego oraz świadectwa wiary zarówno rodziców, jak i wychowawców.

\section{Założenia programowe pracy pedagoga}

U podstaw aktywności zawodowej pedagoga, jak już wyżej zauważono, znajduje się m.in. „Ustawa o systemie oświaty”, „Karta nauczyciela” oraz „Podstawa programowa kształcenia ogólnego" i program wychowawczy przedszkola lub szkoły, w której pedagog jest zatrudniony. Wymienione akty i regulacje prawne odnoszą się do różnych obszarów zaangażowania pedagoga. Wprost nie traktują o zadaniach związanych z kształtowaniem obrazu świętości. W założeniach dotyczących nauczania i wychowania w przedszkolach i szkołach oraz innych placówkach oświatowo-wychowawczych za istotne uznaje się jednak respektowanie chrześcijańskiego systemu wartości i integralnie z nim związanych uniwersalnych zasad etyki ${ }^{34}$. Oznacza to, że w aktywności dydaktyczno-wychowawczej

31 Tamże; Konferencja Episkopatu Polski, Podstawa programowa katechezy Kościoła katolickiego w Polsce, s. 26-28.

32 S. Kulpaczyński, Psychologia rozwojowo-wychowawcza nie tylko dla katechetów, s. 147-148.

${ }_{33}$ Konferencja Episkopatu Polski, Podstawa programowa katechezy Kościoła katolickiego w Polsce, s. 27.

${ }^{34}$ Zob. np. Preambula Ustawy z dnia 7 września 1991 r. o systemie oświaty, poz. 425 z późn. zm. 
pedagog zobowiązany jest kierować się takimi wartościami, jak np. prawda, dobro, piękno, miłość, życie, zdrowie. Z tym wiąże się prawdomówność, odpowiedzialność, rzetelność, mądrość, cierpliwość, wyrozumiałość, pokora, zdolność do ofiary i poświęcenia dla innych, umiejętność udzielania dobrej rady i wsparcia, łagodność, wierność, opanowanie, wytrwałość, gotowość do wybaczania ${ }^{35}$. Wspierając uczniów w integralnym rozwoju, pedagog nie tylko ma przekazywać wiedzę na temat uniwersalnych wartości i ich roli w życiu człowieka, ale także wspierać w kształtowaniu ,poczucia odpowiedzialności, miłości ojczyzny i poszanowania dla polskiego dziedzictwa kulturowego, przy jednoczesnym otwarciu na wartości kultur Europy i świata" ${ }^{36}$. Do jego zadań należy również stwarzanie wychowankom warunków niezbędnych do rozwoju intelektualnego, emocjonalnego, społecznego, moralnego i duchowego oraz towarzyszenie w podejmowaniu decyzji moralnych ${ }^{37}$. Wśród tak ogólnie określonych zadań ważne miejsce zajmuje wspieranie dzieci w nabywaniu umiejętności odróżniania tego, co dobre, od tego, co złe, czyli wartości od antywartości. Niemniej istotną rolę spełnia motywowanie wychowanków do wyboru tego, co jest dobre, co nadaje sens ludzkiej egzystencji oraz umożliwianie samodoskonalenia się i pogłębiania więzi międzyludzkich. Jednocześnie pedagog ma towarzyszyć dzieciom w kształtowaniu zdolności kontrolowania negatywnych emocji, przezwyciężania egocentryzmu oraz nawiązywania serdecznych i życzliwych kontaktów z rówieśnikami ${ }^{38}$. Co więcej, w aktywności zawodowej pedagoga za istotne uznaje się przypominanie wychowankom o godności każdego człowieka, tolerancji, niewyrządzaniu krzywdy innym, uczciwości, wartości życia od poczęcia do naturalnej śmierci, szacunku dla innych, miłości, odpowiedzialności, prostocie i pokorze ${ }^{39}$. To właśnie pedagog, w oparciu o założenia programowe nauczania i wychowania zapisane m.in. w „Podstawie programowej kształcenia ogólnego” oraz w programie wychowawczym przedszkola lub szkoły, w której pracuje, zobowiązany jest odwoływać się do takich wartości, jak: rodzina, przyjaźń, patriotyzm, zdrowie,

${ }^{35}$ Zob. więcej o tym np. w: E. Kobyłecka, Edukacja aksjologiczna w przestrzeni szkolnej codzienności, w: Codzienność szkoły. Uczeń, red. E. Bochno, I. Nowosad, M.J. Szymański, Kraków 2014, s. 131-141.

${ }^{36}$ Preambuła Ustawy z dnia 7 września 1991 r. o systemie oświaty, poz. 425 z późn. zm.

37 Tamże.

38 Rozporzadzenie Ministra Edukacji Narodowej z dnia 17 czerwca 2016 r. zmieniajace rozporzadzenie $w$ sprawie podstawy programowej wychowania przedszkolnego oraz ksztatcenia ogólnego w poszczególnych typach szkót. Załacznik nr 1. Podstawa programowa wychowania przedszkolnego dla przedszkoli oraz innych form wychowania przedszkolnego, poz. 895; Rozporzadzenie Ministra Edukacji Narodowej z dnia 17 czerwca 2016 r. zmieniajace rozporzadzenie $w$ sprawie podstawy programowej wychowania przedszkolnego oraz kształcenia ogólnego $w$ poszczególnych typach szkót. Załącznik nr 2. Podstawa programowa ksztatcenia ogólnego dla szkót podstawowych, poz. 895 .

${ }^{39}$ Ustawa z dnia 7 września 1991 r. o systemie oświaty, poz. 425 z późn. zm.; Ustawa z dnia 26 stycznia 1982 r. Karta Nauczyciela, tekst jednolity ze zmianami, poz. 1379. 
uczciwość, Bóg, honor, ojczyzna, dążenie do doskonałości we wszystkich wymiarach życia ${ }^{40}$. Tak więc, obok wartości witalnych, pedagog ma uwzględniać wartości duchowe i religijne. Do jego zadań należy nie tylko przekaz wiedzy na temat wartości, ale również rozwijanie umiejętności współdziałania w grupie, podejmowanie różnych form aktywności na rzecz innych, zwłaszcza biednych, chorych, starszych, samotnych i angażowanie się w budowanie pokoju i jedności w najbliższym otoczeniu (np. w rodzinie, szkole, grupie rówieśniczej) $)^{41}$. Pedagog w aktywności dydaktyczno-wychowawczej nie może zatem ograniczać się do przekazu wiedzy na temat wartości witalnych, duchowych i absolutnych, ale zobowiązany jest organizować sytuacje edukacyjne, które mają na celu wspieranie dzieci, stosownie do ich właściwości rozwojowych, w akceptowaniu, wyborze i kierowaniu się w życiu wartościami duchowymi i absolutnymi. Stąd też w pracy pedagoga ważne miejsce zajmują odpowiednie rozwiązania organizacyjne i metodyczne, które pozwalają dzieciom zdobywać nowe doświadczenia, rozwijać umiejętność odróżniania wartości od pseudowartości, motywują dzieci do interioryzacji autentycznych wartości i respektowania ich m.in. w domu, w szkole, w kontaktach z rówieśnikami i dorosłymi ${ }^{42}$.

Wyżej opisane założenia programowe pracy pedagoga są niepodważalne i bezsporne. Bazują na naturalnych potrzebach człowieka. Wymagają dostosowania do predyspozycji rozwojowych oraz uwarunkowań społecznych. Obejmują wszystkie sfery życia dziecka, a więc fizyczną, psychiczną, duchową i społeczną. Normują sposób odniesienia i zachowania wobec Boga, innych ludzi i ojczyzny. Wpływają na decyzje i postępowanie dzieci, a przez to na jakość ich życia. Wskazują też na znaczenie procesów internalizacji, dzięki którym wychowankowie nabierają przekonania, że proponowane przez pedagogów wartości są realne, słuszne i godne uwagi ${ }^{43}$. I chociaż zakładane w prawie oświatowym wartości nie odnoszą się wprost do pojęcia ,świętość", to jednak wiążą się integralnie $\mathrm{z}$ tą problematyką. Określają one podstawowe ramy pracy pedagoga $\mathrm{w}$ zakresie kształtowania obrazu świętości wśród dzieci. Wartości wskazują na cele i zadania pracy pedagoga. Co ważne, tylko pozornie ograniczają jego aktywność

40 Tamże; Rozporzadzenie Ministra Edukacji Narodowej z dnia 17 czerwca 2016 r. zmieniajace rozporzadzenie $w$ sprawie podstawy programowej wychowania przedszkolnego oraz ksztatcenia ogólnego w poszczególnych typach szkót. Załącznik nr 1. Podstawa programowa wychowania przedszkolnego dla przedszkoli oraz innych form wychowania przedszkolnego, poz. 895; Rozporządzenie Ministra Edukacji Narodowej z dnia 17 czerwca 2016 r. zmieniające rozporzadzenie $w$ sprawie podstawy programowej wychowania przedszkolnego oraz ksztatcenia ogólnego w poszczególnych typach szkót. Załącznik nr 2. Podstawa programowa ksztatcenia ogólnego dla szkót podstawowych, poz. 895.

${ }^{41}$ Tamże.

${ }^{42}$ Tamże; zob. więcej o tym w: E. Kobyłecka, Edukacja aksjologiczna w przestrzeni szkolnej codzienności, s. 131-141.

${ }^{43}$ Tamże. 
dydaktyczno-wychowawczą. Z uwagi na ich niezaprzeczalny, ponadczasowy, wielowymiarowy i uniwersalny charakter, spełniają ważną rolę m.in. w procesie wspierania dzieci w samopoznaniu i samorozumieniu, przeżywaniu i rozumieniu wartości, odróżnianiu wartości od pseudowartości, formowaniu sumienia, rozwijaniu wrażliwości na potrzeby innych osób oraz kształtowaniu pożądanych społecznie cech osobowości i postaw moralnych ${ }^{44}$. Odniesienie do wartości witalnych, duchowych i absolutnych pozwala pedagogom na podejmowanie różnych inicjatyw, które służą nie tylko stymulowaniu wielostronnej aktywności dzieci, ale także pozwalają kształtować wśród nich właściwy obraz świętości. Wartości spełniają bowiem ważną rolę w rozbudzaniu wśród dzieci pragnienia ofiarowania siebie Bogu i bliźnim w codziennym życiu, np. podczas nauki i zabawy, w kontaktach z rodzicami, rodzeństwem, rówieśnikami. Respektowanie przez dzieci podstawowych wartości w codziennym życiu (np. w szkole, w rodzinie, na placu zabaw, podczas zajęć pozalekcyjnych i pozaszkolnych) pozwala właściwie rozwiązywać codzienne problemy, dokonywać trafnych wyborów, czynić dobro, być uprzejmym, uczynnym, radosnym, cierpliwym i życzliwym oraz gotowym do obrony słabszych i współpracy w grupie, a przez to upodabniać się do Boga.

\section{Rozwiązania metodyczne}

Wynikające z założeń programowych pracy pedagoga granice decyzyjności w zakresie kształtowania obrazu świętości wśród dzieci, obok wymagań programowych w zakresie celów kształcenia i treści dydaktyczno-wychowawczych oraz zadań edukacyjnych, obejmują również rozwiązania metodyczne. W wyżej wymienionych dokumentach oświatowych określa się bowiem w sposób ogólny warunki i sposoby pracy pedagoga w zakresie nauczania i wychowania, uwzględniając przy tym możliwości i potrzeby rozwojowe dzieci ${ }^{45}$.

Zgodnie z założeniami programowymi, pedagog w wychowaniu przedszkolnym ma stwarzać dzieciom okazje do uczenia się w toku organizowanych zabaw, gier, zajęć sportowych, obserwacji przyrodniczych i różnych prac (np. porządkowych, gospodarczych, ogrodniczych $)^{46}$. Takie zadanie wynika wprost

44 Tamże.

${ }^{45}$ Rozporządzenie Ministra Edukacji Narodowej z dnia 17 czerwca 2016 r. zmieniajace rozporzadzenie $w$ sprawie podstawy programowej wychowania przedszkolnego oraz ksztatcenia ogólnego w poszczególnych typach szkót. Załacznik nr 1. Podstawa programowa wychowania przedszkolnego dla przedszkoli oraz innych form wychowania przedszkolnego, poz. 895; Rozporzadzenie Ministra Edukacji Narodowej z dnia 17 czerwca 2016 r. zmieniajace rozporzadzenie $w$ sprawie podstawy programowej wychowania przedszkolnego oraz kształcenia ogólnego $w$ poszczególnych typach szkót. Załacznik nr 2. Podstawa programowa ksztatcenia ogólnego dla szkót podstawowych, poz. 895.

${ }^{46}$ Rozporzadzenie Ministra Edukacji Narodowej z dnia 17 czerwca 2016 r. zmieniajace rozporządzenie w sprawie podstawy programowej wychowania przedszkolnego oraz ksztatcenia ogólne- 
z potrzeb i możliwości rozwojowych wychowanków. Niemniej istotne wydaje się również zobowiązanie pedagogów do włączania rodziców w proces realizacji założeń programowych wychowania przedszkolnego m.in. poprzez współdecydowanie w sprawach wychowawczych i organizowanie wydarzeń z udziałem dzieci i ich rodziców ${ }^{47}$. Z kolei w szkole podstawowej - na etapie edukacji wczesnoszkolnej - osiąganiu zakładanych celów i treści służą zróżnicowane, dostosowane do możliwości rozwojowych uczniów, metody nauczania i środki dydaktyczne, wzbogacone o zabawy i gry edukacyjne oraz sytuacje zadanio$w^{48}$. Wskazuje się też na konieczność łączenia w pracy pedagogicznej z dziećmi różnych rozwiązań metodycznych oraz pobudzania wyobraźni, prowadzenia dialogu i koordynowania działań zespołowych (w małych grupach) ${ }^{49}$. Co więcej, ,ze względu na specyfikę dziecięcego rozumowania" ${ }^{50}, \mathrm{w}$ trakcie zajęć za istotną w pracy pedagoga uznaje się ,analizę zachowania postaci literackich (z baśni, bajek, opowiadań itp.), filmowych i telewizyjnych"51. Zastosowanie przez pedagoga tego rodzaju rozwiązań metodycznych sprzyja osiąganiu celów związanych ze wspieraniem dzieci w rozwijaniu cech osobowości, które są konieczne do aktywnego, odpowiedzialnego, respektującego podstawowe zasady i wartości uczestnictwa w życiu społecznym. Stanowi zatem okazję do kształtowania postaw, jakimi odznaczają się osoby, które dążą do świętości. Niezwykle istotną rolę spełniają jednak odpowiednie, zaprojektowane przez pedagoga i zastosowane podczas zajęć edukacyjnych, sytuacje aksjologiczne, czyli „konstrukty teoretyczne odwzorowujące rzeczywiste funkcjonowanie wartości w świecie"s2. Punktem wyjścia każdej tego rodzaju sytuacji jest człowiek i jego postępowanie, w którym uwidaczniają się m.in. stawiane przez niego cele, aspiracje i dążenia życiowe, dokonywane wybory oraz podejmowane decyzje i działania ukierunkowane na rozwiązywanie problemów życiowych ${ }^{53}$. Aktywny udział dzieci w różnych sytuacjach aksjologicznych sprzyja przeżywaniu i rozumieniu wartości oraz konfrontowaniu swoich dotychczasowych

go w poszczególnych typach szkót. Załacznik nr 1. Podstawa programowa wychowania przedszkolnego dla przedszkoli oraz innych form wychowania przedszkolnego, poz. 895.

47 Tamże.

${ }^{48}$ Rozporzadzenie Ministra Edukacji Narodowej z dnia 17 czerwca 2016 r. zmieniajace rozporzadzenie w sprawie podstawy programowej wychowania przedszkolnego oraz ksztatcenia ogólnego w poszczególnych typach szkół. Załącznik nr 2. Podstawa programowa kształcenia ogólnego dla szkót podstawowych, poz. 895.

49 Tamże.

${ }^{50}$ Rozporzadzenie Ministra Edukacji Narodowej z dnia 17 czerwca 2016 r. zmieniajace rozporządzenie w sprawie podstawy programowej wychowania przedszkolnego oraz kształcenia ogólnego w poszczególnych typach szkót. Załacznik nr 2. Podstawa programowa kształcenia ogólnego dla szkót podstawowych, poz. 895.

51 Tamże.

${ }_{52}$ E. Kobyłecka, Edukacja aksjologiczna w przestrzeni szkolnej codzienności, s. 136.

${ }^{53}$ Tamże. 
poglądów i postaw ${ }^{54}$. Motywuje też do dialogu na temat wybieranych przez siebie wartości i akceptowanych sposobów postępowania wobec innych osób. Uwrażliwia przy tym na prawdę, dobro, piękno i miłość. Pozwala dostrzec ambiwalencję tych wartości w świecie oraz konsekwencje dokonywanych wyborów. Wzmacnia też przekaz wiedzy, rozbudza pragnienie bycia dobrym i szlachetnym oraz motywuje do rozwoju cech osobowości człowieka, który pragnie być świętym. Dostarcza bowiem bodźców umożliwiających zrozumienie, co oznaczają słowa „taki mały taki duży może świętym być” ${ }^{55}$, a przy tym sprzyja rozwijaniu umiejętności życia prawdą o sobie oraz skłania do refleksji nad własnym postępowaniem i motywuje do czynienia dobra w najbliższym otoczeniu (np. w rodzinie, szkole).

Aby stosowane przez pedagoga rozwiązania metodyczne okazały się skuteczne i przyczyniały się do kształtowania właściwego obrazu świętości, konieczne jest oddziaływanie własnym przykładem. Dziecko w wieku przedszkolnym i wczesnoszkolnym uczy się głównie przez obserwację i naśladownictwo tych, którzy są dla niego autorytetem ${ }^{56}$. Potrzebuje zatem wzorców nie tylko w postaci rodziców, ale również pedagogów. Ucząc się od znaczących dla niego osób dorosłych, dziecko doświadcza, na czym polega bycie świętym w codziennym życiu. Dobra znajomość dzieci, ich potrzeb, poglądów i preferencji aksjologicznych, empatia oraz miłość i szacunek okazywany wychowankom, motywują do postrzegania pedagoga jako autorytetu i naśladowania go w dobrym postępowaniu.

\section{Innowacje pedagogiczne}

Współczesne dziecko napotyka na wiele trudności w zakresie rozpoznawania wartości świętości, odróżniania tego co dobre od tego co złe, zwłaszcza że kultura ponowoczesności narzuca niewłaściwe obrazy i postawy wobec życia, śmierci, starości, samego siebie, drugiego człowieka i Boga ${ }^{57}$. Na przykład, zaczerpnięte z kultury amerykańskiej i szeroko rozpowszechnione w kulturze europejskiej święto Halloween, sprzyja wzbudzaniu wśród dzieci zainte-

\footnotetext{
54 Tamże, s. 136-137.

${ }_{55}$ Arka Noego, Święty uśmiechnięty, https://www.youtube.com/watch?v=-Pjn0ARITRY [dostęp 12.10.2016].

${ }^{56}$ Konferencja Episkopatu Polski, Podstawa programowa katechezy Kościoła katolickiego w Polsce, s. 15-17; 26-28.

${ }^{57}$ Zob. o tym np. w: M. Dziewiecki, Ponowoczesność - czlowiek - wychowanie, http:// www.opoka.org.pl/biblioteka/I/ID/ponowoczesnosc_wychowanie.html [dostęp 12.10.2016], s. 1-6; A. Schmidt, Sytuacja dziecka w obecnym świecie - blaski i cienie wspótczesnego dzieciństwa, http://blizejprzedszkola.pl/temat-38,890,sytuacja-dziecka-w-obecnym-swiecie [dostęp 12.10.2016], s. 1-4.
} 
resowania magią, czarami, upiorami i złymi duchami ${ }^{58}$. W Polsce tego dnia coraz więcej dzieci przebiera się za czarownicę, wampira, ducha czy diabła, aby wzbudzić w czasie zabawy grozę, strach, lęk wśród innych osób (także dorosłych). Chrześcijańska tradycja uroczystości Wszystkich Świętych wśród dzieci przestaje odgrywać znaczącą rolę. Zwycięża natomiast moda i presja medialno-finansowa, która utrwala nowy, pozornie niewinny, neopogański styl zabawy w dniach poprzedzających uroczystość Wszystkich Świętych i wspomnienie Wszystkich Wiernych Zmarłych ${ }^{59}$. W tej sytuacji potrzebne jest zaangażowanie pedagoga w poszukiwanie nowych, niekonwencjonalnych rozwiązań programowych i metodycznych, które mają na celu modyfikację oraz poszerzenie realizowanych w przedszkolu i w szkole działań w obszarze kształtowania obrazu świętości wśród dzieci. Niewątpliwie na uwagę zasługują bale „Wszystkich Świętych", organizowane dla chętnych dzieci, ich rodziców i rodzeństwa we współpracy z parafią, na terenie której znajduje się szkoła oraz gry edukacyjne promujące wartości na przykładzie konkretnych postaci świętych ${ }^{60}$. Niemniej istotne znaczenie wychowawcze mają projekty edukacyjne $\mathrm{z}$ udziałem dzieci i ich rodziców czy też koncerty, inscenizacje, konkursy i festyny rodzinne poświęcone problematyce świętości. Mogą być one okazją do wspólnej zabawy i promocji uniwersalnych wartości. Służą też budowaniu więzi w rodzinie oraz integracji społecznej.

Podobne znaczenie wychowawcze ma organizowanie „Dnia Anioła” w przedszkolu lub w szkole ${ }^{61}$. Tego rodzaju rozwiązanie metodyczne nie tylko sprzyja dobrej zabawie, ale także stwarza okazję do podejmowania bezinteresownych form pomocy osobom chorym, samotnym, wykluczonym społecznie. W praktyce „Dzień Anioła” może być także okazją do czynienia dobra w społeczności szkol-

${ }^{58}$ Szerzej na ten temat pisze np. J. Cielecki, Nie igrać z Halloween, http://www.naszdziennik. pl/mysl/106049,nie-igrac-z-halloween.html [dostęp: 27.10.2016], s. 1-3; A. Posacki, Halloween jako celebracja okultyzmu $i$ satanizmu, http://www.petrus.kielce.opoka.org.pl/pliki/pdf/Posacki_A_Halloween_jako_celebracja_okultyzmu_i_satanizmu_Diabelskie_sieci_na_nasze_dzieci. pdf [-̄ostęp: 31.10.2016], s. 1-4.

59 Tamże; zob. także: A. Stelmach, Strzeżcie dzieci przed pogańskim halloween, http://www. pch24.pl/strzezcie-dzieci-przed-poganskim-halloween,7056,i.html [dostęp: 29.10.2016], s. 1-3.

${ }^{60}$ Zob. opis dobrych, a zarazem innowacyjnych praktyk w tym zakresie np. w: Bale Wszystkich Świętych na Pomorzu, http://www.dziennikbaltycki.pl/wiadomosci/a/bale-wszystkich-swietych-na-pomorzu-zdjecia-wideo,11334479/ [dostęp 31.10.2016], s. 1-2; Korowody i bale Wszystkich Świętych, http://www.tvp.info/27549430/korowody-i-bale-wszystkich-swietych [dostęp 31.10.2016], s. 1; Korowody świętych w catym kraju, https://ekai.pl/diecezje/poznanska/x104706/ korowody-swietych-w-calym-kraju/ [dostęp 3.11.2016], s. 1-2.

${ }^{61}$ Zob. o tym np. w: http://www.kspinowroclaw.pl/archiwum/dzie\%C5\%84-aniola/ [dostęp: 2.11.2016]; http://www.pm106.p1/2015/10/02/dzien-aniola/ [dostęp 2.11.2016]; http:// sp2miechow.szkolnastrona.pl/index.php? $\mathrm{p}=$ new\&idg=mg,28\&id=295\&action=show [dostęp 2.11.2016]. 
nej i klasowej. To sam pedagog, kierując się potrzebami edukacyjnymi dzieci oraz uwarunkowaniami społecznymi i organizacyjnymi, zobowiązany jest do zaplanowania - we współpracy z rodzicami i innymi nauczycielami - określonych działań. Wymaga to kreatywnego przekraczania zastanych założeń programowych w zakresie metodyki nauczania i wychowania na etapie edukacji przedszkolnej i wczesnoszkolnej.

\section{Uwagi końcowe}

Pedagog w swojej pracy zawodowej ma zagwarantowaną pomoc w formie dokumentów oświatowych, które określają cele i zadania oraz treści nauczania i wychowania. Nie oznacza to jednak bezrefleksyjnego powielania założeń programowych. Przeciwnie, wymaga kreatywności w myśleniu i działaniu, w tym dostosowania różnorodnych rozwiązań metodycznych do potrzeb rozwojowych dzieci i wyzwań edukacyjnych. Stąd też granice decyzyjności pedagoga w odniesieniu do kształtowania obrazu świętości są niekwestionowane tylko w obszarze merytorycznym. Wiążą się bowiem z przyjętą $\mathrm{w}$ edukacji przedszkolnej i szkolnej aksjologią oraz z przekazem wiedzy o wartościach i kształtowaniem postaw. Co ważne, zostały opisane w dokumentach programowych nauczania i wychowania realizowanego w przedszkolu i w szkole, dlatego mają charakter obowiązujący wszystkich pedagogów, którzy w ramach zatrudnienia w przedszkolu lub w szkole uczestniczą w realizacji funkcji opiekuńczych, dydaktycznych i wychowawczych. Innymi słowy, przepisy oświatowe nakładają na pedagoga obowiązek uwzględniania założeń programowych właściwych dla określonego typu placówki przedszkolnej i szkoły oraz etapu edukacyjnego.

Wielorakie możliwości twórczej pracy pedagoga w zakresie kształtowania obrazu świętości wśród dzieci stwarzają natomiast opisane w prawie oświatowym wskazania metodyczne. Nie tylko można je modyfikować i wzbogacać o nowe rozwiązania, ale należy to czynić w sposób kreatywny. Tworzenie nowych, oryginalnych elementów sprzyja przekraczaniu barier związanych z kształtowaniem obrazu świętości wśród dzieci. Pozwala odwołać się do dobrych praktyk edukacyjnych, dokonać ich reorganizacji i wzbogacić o twórcze rozwiązania. Nie wystarczą tu jedynie kompetencje merytoryczne i metodyczne. Potrzebne są również kompetencje aksjologiczne. Tylko pedagog o wysokich kompetencjach aksjologicznych może wspierać dzieci w rozpoznawaniu wartości, które są niezbędne w kształtowaniu właściwego obrazu świętości oraz stwarzać warunki do ich internalizacji i nabywania umiejętności ich stosowania w życiu. 


\section{(Un)questionable boundaries of a teacher's decision-making in shaping the image of sanctity among children?}

\section{Summary}

A teacher's work with children of preschool and early school age focuses on achieving the teaching and educational objectives, as well as those related to childcare. The tasks include, among others, supporting pupils in shaping the image of the world, recognising different values and criteria, as well as methods of choosing them, obtaining basic social skills, and shaping moral and religious attitudes. The educator is obliged to show the children universal values and ethical principles. They also have to present role models and motivate their pupils to imitate them. All of this fosters an image of sanctity among children.

When it comes to making decisions regarding the shaping of the image of sanctity among children, the teacher is restricted by educational law, especially the core curriculum of general education, as well as the school's curriculum. This restriction applies mainly to the objectives and content of teaching and education. However, in matters of methodology, the teacher has many possibilities for creative action. They may exceed the methodologies suggested by educational law and design their own teaching innovations. With regard to shaping the image of sanctity among children, of particular note are All Saints' Day balls, Angel Days, educational games and activities, family fairs, saints' parades, competition and stage productions.

\section{Keywords}

pedagogy, education, sanctity, educator, children, values

\section{Slowa kluczowe}

pedagogika, edukacja, świętość, pedagog, dzieci, wartości

\section{Bibliografia}

Arka Noego, Święty uśmiechnięty, https://www.youtube.com/watch?v=-Pjn0ARITRY [dostęp 12.10.2016].

Bagrowicz J, Towarzyszyć wzrastaniu. Z dyskusji o metodach i środkach edukacji religijnej młodzieży, Torun 2006.

Bale Wszystkich Świętych na Pomorzu, http://www.dziennikbaltycki.pl/wiadomosci/a/bale-wszystkich-swietych-na-pomorzu-zdjecia-wideo,11334479/ [dostęp: 31.10.2016], s. 1-2.

Banach Cz., Wartości w systemie edukacji, http://www.wsp.krakow.pl/konspekt/konspekt7/banach7.html [dostęp 12.10.2016].

Baran G., Świętość. II. W Biblii, w: Encyklopedia katolicka, t. 19, red. E. Gigilewicz, Lublin 2013, kol. 401-403.

Bednarska M.A. (red.), O autorytecie w wychowaniu i nauczaniu, Wrocław 2009.

Brzezińska A.I., Appelt K., Ziółkowska B., Psychologia rozwoju człowieka, Sopot 2016. Budzyńska K., Bajki terapeutyczne i ich rola, „Życie Szkoły” 11(2013), s. 8-9.

Cholewa M., Psychologia rozwojowa, Kraków 2015. 
Cielecki J., Nie ograć z Halloween, http://www.naszdziennik.pl/mysl/106049,nie-igrac-z-halloween.html [dostęp 27.10.2016], s. 1-3.

Decyzyjność., http://sjp.pwn.pl/sjp/;3028672 [dostęp 10.10.2016].

Dziewiecki M., Ponowoczesność - człowiek - wychowanie, http://www.opoka.org.pl/biblioteka/I/ID/ponowoczesnosc_wychowanie.html [dostęp 12.10.2016], s. 1-6.

Furmanik K., Wczesne uwarunkowania obrazu Boga, http://www.opoka.org.pl/bibliote$\mathrm{ka} / \mathrm{I} / \mathrm{IP} / \mathrm{kf}$ _obraz-boga.html, [dostęp 22.10.2016], s. 1-8.

http://sp2miechow.szkolnastrona.pl/index.php?p=new\&idg=mg,28\&id=295\&action= show [dostęp 2.11.2016].

http://www.kspinowroclaw.pl/archiwum/dzie\%C5\%84-aniola/ [dostęp 2.11.2016]. http:// www.pm106.pl/2015/10/02/dzien-aniola/ [dostęp: 2.11.2016].

Kasprzak M., Miejsce św. Józefa w katechezie na I, II i III etapie edukacyjnym, „Katecheta" 58(2012) nr 12, s. 4-10.

Kobyłecka E., Edukacja aksjologiczna w przestrzeni szkolnej codzienności, w: Codzienność szkoły. Uczeń, red. E. Bochno, I. Nowosad, M.J. Szymański, Kraków 2014, s. 131-141.

Kołodziejski M (red.), Twórcza codzienność w kształceniu i wychowaniu: teoria i praktyka edukacyjna, Pułtusk 2014.

Konferencja Episkopatu Polski, Podstawa programowa katechezy Kościoła katolickiego w Polsce, Kraków 2010.

Korowody i bale Wszystkich Świętych, http://www.tvp.info/27549430/korowody-i-bale-wszystkich-swietych [dostęp 31.10.2016], s. 1.

Korowody świętych w calym kraju, https://ekai.pl/diecezje/poznanska/x104706/korowody-swietych-w-calym-kraju/ [dostęp 3.11.2016], s. 1-2.

Królikowski P., Rusecki M., Świętość Kościoła, w: Encyklopedia katolicka, t. 19, red. E. Gigilewicz, Lublin 2013, kol. 404-407.

Kulpaczyński S., Psychologia rozwojowo-wychowawcza nie tylko dla katechetów, Lublin 2009.

Kupisiewicz Cz., Kupisiewicz M., Słownik pedagogiczny, Warszawa 2009.

Langier C., Bajki i baśnie jako źródło wartości w wychowaniu moralnym dzieci, w: Edukacja dziecka wobec wyzwań i zagrożeń ponowoczesności, red. C. Langier, K. Śleziński, Częstochowa 2014, s. 97-208.

Lubina E. (red.), Małe dziecko w przestrzeni społecznej i edukacyjnej, Warszawa 2012.

Łużyńska D. (red.), Autorytet w wychowaniu i edukacji, Józefów 2013.

Marek Z, Szczęsny M, Szołda B, Warchał T., Bóg w przedszkolu i szkole. Zarys katechezy przedszkolnej $i$ wczesnoszkolnej, Kraków 2000.

Mąkosa P., Rola katechezy w kształtowaniu obrazu Boga u dzieci w młodszym wieku szkolnym, w: Katecheza dzieci. Red. M. Zając. Lublin 2009, s. 169-185.

Milerski B., Śliwerski B. (red.), Pedagogika. PWN Leksykon, Warszawa 2000.

Okoń W., Nowy stownik pedagogiczny, Warszawa 1998.

Posacki A., Halloween jako celebracja okultyzmu i satanizmu, http://www.petrus.kielce. opoka.org.pl/pliki/pdf/Posacki_A_Halloween_jako_celebracja_okultyzmu_i_satanizmu_Diabelskie_sieci_na_nasze_dzieci.pdf [dostęp 31.10.2016], s. 1-4.

Preambuła Ustawy z dnia 7 września 1991 r. o systemie oświaty, poz. 425 z późn. zm.

Przetacznik-Gierowska M., Makiełło-Jarża G., Psychologia rozwojowa i wychowawcza wieku dziecięcego, Warszawa 1992. 
Rozporzadzenie Ministra Edukacji Narodowej z 18 sierpnia 2015 r. w sprawie zakresu i form prowadzenia $w$ szkołach i placówkach systemu oświaty działalności wychowawczej, edukacyjnej, informacyjnej i profilaktycznej $w$ celu przeciwdziałania narkomanii, „Dziennik Ustaw” z 2015, poz. 1249.

Rozporzadzenie Ministra Edukacji Narodowej z dnia 17 czerwca 2016 r. zmieniajace rozporzadzenie $w$ sprawie podstawy programowej wychowania przedszkolnego oraz kształcenia ogólnego w poszczególnych typach szkót. Załącznik nr 1. Podstawa programowa wychowania przedszkolnego dla przedszkoli oraz innych form wychowania przedszkolnego, „Dziennik Ustaw” z 2016, poz. 895.

Rozporzadzenie Ministra Edukacji Narodowej z dnia 17 czerwca 2016 r. zmieniajace rozporzadzenie $w$ sprawie podstawy programowej wychowania przedszkolnego oraz kształcenia ogólnego w poszczególnych typach szkót. Załacznik nr 2. Podstawa programowa kształcenia ogólnego dla szkół podstawowych, „Dziennik Ustaw” z 2016, poz. 895 .

Rybicki A., Świętość. III. W teologii, w: Encyklopedia katolicka, t. 19, red. E. Gigilewicz, Lublin 2013, kol. 403-404.

Schaffer H.R., Psychologia dziecka, Warszawa 2005.

Schmidt A., Sytuacja dziecka w obecnym świecie - blaski i cienie współczesnego dzieciństwa, http://blizejprzedszkola.pl/temat-38,890,sytuacja-dziecka-w-obecnym-swiecie [dostęp 12.10.2016], s. 1-4.

Smith P.K., Rozwój społeczny, w: Psychologia rozwojowa, red. P.E. Bryant, A.M. Colman, tłum. A. Bezwińska-Walerjan, Poznań 1995, s. 60-86.

Stefańska-Klar R., Późne dzieciństwo. Młodszy wiek szkolny, w: Psychologia rozwoju człowieka, t. 2, Charakterystyka rozwoju człowieka, red. B. Harwas-Napierała, J. Trempała, Warszawa 2000, s. 130-162.

Stelmach A., Strzeżcie dzieci przed pogańskim halloween, http://www.pch24.pl/strzezcie-dzieci-przed-poganskim-halloween,7056,i.html [dostęp 29.10.2016], s. 1-3.

Ustawa z dnia 7 września 1991 r. o systemie oświaty, „Dziennik Ustaw” 1991 nr 95, poz. $425 \mathrm{z}$ późn. zm.

Ustawa z dnia z dnia 26 stycznia 1982 r. Karta Nauczyciela, „Dziennik Ustaw” z 1982 nr 3, poz. 19, z późn. zm. tekst jednolity „Dziennik Ustaw” 2016 r. poz. 1379.

Waloszek, Dziecko, w: Encyklopedia pedagogiczna XXI wieku, red. T. Pilch, t. 1, Warszawa 2003, s. 883-895.

Wawro F.W. (red.), Pedagog wobec wyzwań współczesności, Lublin 2010.

Werbiński I., Błogosławiona Karolina Kózka jako wzór osobowy dla współczesnej młodzieży żeńskiej, „Ateneum Kapłańskie” 134(2000), s. 33-40.

Wołoszynowa L., Młodszy wiek szkolny, w: Psychologia rozwojowa dzieci i młodzieży, red. M. Żebrowska, Warszawa 1982, s. 522-663.

Żurek A., Style wychowania doświadczane $w$ dzieciństwie jako korelaty religijności osób dorostych. Pilotażowe badania empiryczne wśród rodziców dzieci przygotowujacych się do sakramentu Eucharystii, „Studia Paradyskie” 25(2015), s. 229-246. 